\title{
Determination of Fragrance Allergens in Essential Oils and Evaluation of their in vitro Permeation from Essential Oil Formulations through Cultured Skin
}

\author{
Lai-Hao Wang*, Hung-Jiun Liu \\ Department of Applied Chemistry, Chia Nan University of Pharmacy and Science, Tainan 71743, Taiwan
}

\begin{abstract}
We developed a high-performance liquid chromatography method using fluorometric detection to simultaneously determine the allergens in fragrances, primarily structurally related allylbenzenes in essential oils. The effect of essential oil carriers-cloves, basil, and cinnamon-on the release and percutaneous absorption of the oils was studied in vitro using a cultured epidermal autograft membrane model.
\end{abstract}

Keywords: Allergens of fragrance; Essential oil formulations; Permeation through cultured skin; Fluorometric detection

\section{Introduction}

Research on essential oils is popular; however, almost all studies focus on their extraction, chemical composition, and wide application in the food and cosmetics industries and traditional medicine. Fragrances are widely encountered in our daily environment and are known to be a common cause of allergic contact dermatitis. Quantitative analysis of fragrance substances that are well-known allergens in cosmetic and essential oil products, such as cinnamic alcohol, isoeugenol, and eugenol in ylang-ylang oil and jasminum, have been extensively studied over the past 10 years (Schlede et al., 2008; Schreiner et al., 2008; Villa et al., 2007; David et al., 2006; Tomar et al., 2005; An et al., 2005; Leijs et al., 2005; Cadby et al., 2003). The major analytical methods for analyzing fragrances are gas chromatography, gas chromatography-mass spectrometry (Schulz et al., 2008a; Schulz et al., 2008b; Polzin et al., 2007; Elzaawely et al., 2007; Yu et al., 2007; Bianchi et al., 2007; Kim et al., 2006; Sánchez-Palomo et al., 2005; Peña-Alvarez et al., 2006; Lukić et al., 2006 ; Mitja et al., 2006; Besharati-Seidani et al., 2005; Luan et al., 2005; Hérent et al., 2007), minor liquid chromatography (Villa et al., 2007; Li et al., 2007; Li et al., 2008; Rauber et al., 2005), micellar electrokinetic capillary chromatography (Huhn et al., 2008; Hanson et al., 2005), and vibrational spectroscopy (Schulz et al., 2003). The in vitro evaluation of fragrance materials such as camphor, carvone, 1 , 8-cineole, linalool, menthol, thujone, menthone, t-anethole, through the human epidermis has already been studied (Gabbanini et al., 2009; Zhang et al., 2006).

Few reports focus on the influence of aromatic essential oils on skin permeation, because the fragrances of these oils are complicated and difficult to characterize (Weyers and Brodbeck, 1989; Weibel and Hansen, 1989; Gabbanini et al., 2009). There are few reports in the literature on using liquid chromatography with fluorometric detection to determine fragrance levels in essential oils and evaluate in vitro percutaneous absorption of essential oil formulations through cultured skin. We used the sensitivity and specificity of fluorometric detection to determine fragrance levels, and a cultured epidermal autograft membrane model for an in vitro study of the percutaneous absorption of the essential oils; it is more specific because it eliminates interference from natural essential oils.

\section{Experimental}

\section{Apparatus and materials}

High performance liquid chromatography (HPLC) was done using both a Hitachi model L-7100 pump and model 7125 injector equipped with a $20-\mu \mathrm{L}$ sample loop and with a fluorometric detector (RF-10AXL; Shimadzu). Chromatograms were acquired and peak areas calculated (D-7000 HPLC System Manager Software; Hitachi). Fragrances with allergens were purchased: cinnamyl alcohol and eugenol methyl ether (Chem Service, Inc., West Chester, PA, USA); eugenol, isoeugenol, and anethole 99\% (Acros Organics, Geel, Belgium); $\alpha$-asarone, myristicin, and safrole (Fluka Chemie AG, Buchs, Switzerland and RDH Laborchemikalien GmbH \& Co KG, Seelze, Germany); and 4-Allylanisole (Aldrich Chemical Company, Inc., Milwaukee, WI, USA). The structurally related allergens are shown in Scheme 1. Phosphate buffered saline was obtained from Hyclone (Thermo Fisher Scientific Inc., Waltham, MA, USA). All other chemicals were of analytical reagent grade. Samples of 11 essential oils obtained local department store or retail grocern and drug food cosmetic outlet. They were labeled as $100 \%$ natural products.

\section{Determining fragrances using HPLC}

The stationary phase was a Phenomenex $C_{18}$ column $(5 \mu \mathrm{m}$, i.d.: $4.6 \times 250 \mathrm{~mm})$, and the eluent was a mixture of methanol-water (70:30 $(\mathrm{v} / \mathrm{v}), \mathrm{pH} 3.52)$ and acetonitrile-methanol-water [10:50:40 ( $/ \mathrm{V} / \mathrm{v})$, 20:40:40 $(v / v / v), 30: 30: 40(v / v / v)$, and 40:40:20, $(v / v / v)]$, containing 1 $\mathrm{mM}$ of phosphoric acid adjusted at $\mathrm{pH} 3.45,4.13,5.13,6.03,7.03$, and 7.78 . The eluent flow rate was $1.0 \mathrm{~mL} / \mathrm{min}$, and the fluorometric detector was operated at an Ex (excitation wavelength) of $230 \mathrm{~nm}$ and an Em (emission wavelength) of $317 \mathrm{~nm}$. After various analyses of the retention behavior of the fragrances, baseline separation was achieved. Acetonitrile-methanol-water (30:30:40 (v/v/v), pH 6.02) was the best eluent for a good resolution and for the fewest peak interferences in the matrix. Sample and standard solutions $(20 \mu \mathrm{L})$ were injected using an injection valve.

\section{In vitro skin permeation}

The permeation of fragrances in vitro was investigated using

*Corresponding author: Lai-Hao Wang, Department of Applied Chemistry, Chia Nan University of Pharmacy and Science, Tainan 71743, Taiwan, E-mail: e201466. wang@msa.hinet.net

Received May 09, 2010; Accepted June 10, 2010; Published June 10, 2010

Citation: Wang LH, Liu HJ (2010) Determination of Fragrance Allergens in Essential Oils and Evaluation of their in vitro Permeation from Essential Oil Formulations through Cultured Skin. J Bioequiv Availab 2: 072-076. doi:10.4172 jbb. 1000034

Copyright: @ 2010 Wang LH, et al. This is an open-access article distributed under the terms of the Creative Commons Attribution License, which permits unrestricted use, distribution, and reproduction in any medium, provided the original author and source are credited. 


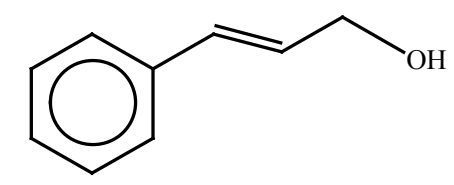

Cinnamyl alcohol

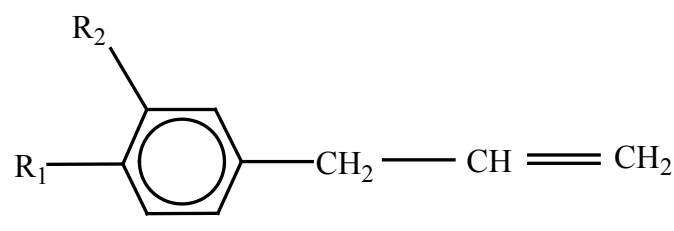

Eugenol $\quad \mathrm{R}_{1}=\mathrm{OH}, \mathrm{R}_{2}=\mathrm{OCH}_{3}$

Eugenol methyl ether $\mathrm{R}_{1}=\mathrm{OCH}_{3}, \mathrm{R}_{2}=\mathrm{OCH}_{3}$

Estragole $\quad \mathrm{R}_{1}=\mathrm{OCH}_{3}, \mathrm{R}_{2}=\mathrm{H}$

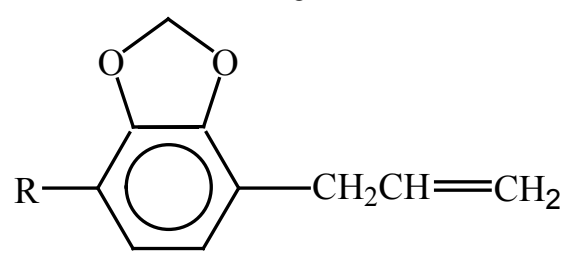

Safrole $\quad \mathrm{R}=\mathrm{H}$

Myristicin $\mathrm{R}=\mathrm{OCH}_{3}$

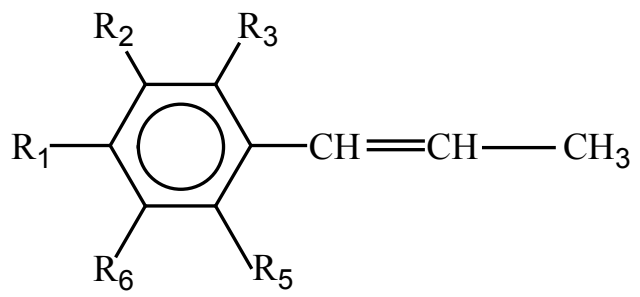

Anethole $\mathrm{R}_{2}=\mathrm{R}_{3}=\mathrm{R}_{5}=\mathrm{R}_{6}=\mathrm{H}, \mathrm{R}_{1}=\mathrm{OCH}_{3}$

$\alpha$-Asarone $\mathrm{R}_{3}=\mathrm{R}_{5}=\mathrm{H}, \mathrm{R}_{1}=\mathrm{R}_{2}=\mathrm{R}_{6}=\mathrm{OCH}_{3}$

Isoeugenol $\mathrm{R}_{3}=\mathrm{R}_{5}=\mathrm{R}_{6}=\mathrm{H}, \mathrm{R}_{2}=\mathrm{OCH}_{3}, \mathrm{R}_{1}=\mathrm{OH}$

Scheme 1: The fragrance structures of cinnamyl alcohol and allylbenzenes derivatives.

a horizontal diffusion cell or a side-bi-side cell constructed in our laboratory (Scheme 2). The diffusion cells consisted of two waterjacketed cylindrical half-cells, each with a permeation area of about 9.6 $\mathrm{cm}^{2}$. A freshly cultured epidermal autograft membrane cell line (CAL2309) was obtained from the Animal Technology Institute of Taiwan (http://www.atit.org.tw/english/index e.htm). Microphotographs of the membranes used for the study were examined for integrity, and then immediately mounted in the diffusion cells. One of the receptor compartments $(11 \mathrm{~mL})$ was filled with phosphate buffered saline (PBS) as the cell culture medium; the other contained $0.08 \% \mathrm{w} / \mathrm{v}$ of essential oil micro cream. The less surfactant, the less irritation with topical use can be expected. We investigated four different preparations-A-Dwithout Tween 80 surfactant (A) but with various amount of Tween 80 surfactants (B-D). To test the effect of essential oil, all preparations (B-D) were mixed with increasing amounts $(0.0184 \%, 0.0245 \%$, and $0.08 \%$ ) of clove essential oil for B, C, and D preparations, respectively. Emulsifier (surfactant) solubilizes essential oil in water and produces a clear o/w emulsion. A contained $0.0184 \%$ clove essential oil without emulsifier (Tween 80 ), B contained $0.0184 \%$ clove essential oil and $0.1 \%$ Tween 80 , C contained $0.0245 \%$ clove essential oil and $0.2 \%$ Tween 80 , and D contained $0.08 \%$ clove essential oil and $0.5 \%$ Tween
80 in the receptor The formulation consisted of $9.5 \mathrm{~g}$ of water, $0.33 \mathrm{~g}$ of Tween 80 (a non-ionic surfactant and emulsifier), $0.17 \mathrm{~g}$ of stearic acid, and $0.008 \mathrm{~g}$ of essential oil. The diffusion cells were kept at a constant temperature by circulating water at $37^{\circ} \mathrm{C}$. The receptor solution was stirred during the experiment to ensure thorough mixing.

At defined time intervals $(0,10,20,30,60,90,120,180,240,360$, $420,480,600$, and $720 \mathrm{~min}), 1 \mathrm{~mL}$ of receptor samples was removed for analysis and replaced with fresh receptor medium. The sample was extracted using three $3-\mathrm{mL}$ portions of $\mathrm{n}$-hexane. The organic phase was collected and evaporated under nitrogen at a temperature $<37^{\circ} \mathrm{C}$. Samples were reconstituted with methanol $(2 \mathrm{~mL})$, vortexmixed, and then filtered through $0.45-\mu \mathrm{m}$ PVDF membrane filters before LC analysis.

\section{Results and Discussion}

\section{Optimization of chromatographic conditions}

The objective of this study was to develop an HPLC assay for simultaneously determining fragrances in essential oils and in cultured epidermal autograft membrane. Five different eluents with various compositions were prepared and listed in Table 1. With methanolwater $(70: 30, v / v)$ as the eluent, the retention times of safrole, 4-allylanisole, and trans-anethole were 19.73, 22.45, and $27.37 \mathrm{~min}$, respectively. Table 1 shows the effect of acetonitrile concentration in the mobile phase on the capacity factors and sensitivity. However, acetonitrile-methanol-water (10:50:40 and 20:40:40) failed to resolve the solute eugenol and isoeugenol. The 20:40:40 eluent was too polar for the rapid elution of fragrances. Various $\mathrm{pH}$ (3.45-7.78) of acetonitrile-methanol-water (30:30:40, $v / v / v)$ were experimented with on fragrances. After various studied of retention behaviour of the fragrances, baseline separation was achieved. Acetonitrile-methanolwater (30:30:40, $v / v / v, \mathrm{pH}$ 6.02) was found to be the best mobile phase for a good resolution and for the least peak interferences in the matrix. Therefore, it used as the mobile phase and the Phenomenex $\mathrm{C}_{18}$ analytical column (particle size $5 \mu \mathrm{m}, 4.6 \times 250 \mathrm{~mm}$ i.d.) was the stationary phase. A typical HPLC trace under optimum conditions is shown in Figure 1.

The standard curves for all nine compounds were determined simultaneously at Ex $230 \mathrm{~nm}$ and Em $317 \mathrm{~nm}$. Using the procedure described, the limits of detection for fragrances were 0.009-0.144 $\mathrm{ng} \mathrm{mL}^{-1}$. All calibration curves were linear in the ranges measured: 12.5-1000 ng mL $\mathrm{m}^{-1}$ for most fragrances and 2500-10000 $\mathrm{ng} \mathrm{mL}^{-1}$ for $\alpha$-asarone and myristicin, respectively. To evaluate the reproducibility of our results, six measurements using the same chromatographic parameters were made of the same fragrances. The relative standard

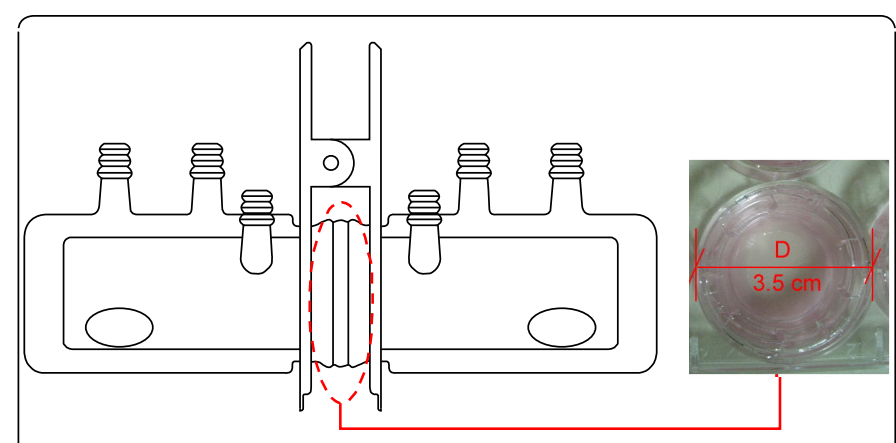

Scheme 2: Diagram of horizontal diffusion cell in vitro skin permeation. 


\begin{tabular}{|l|l|l|l|l|}
\hline Fragrances & $\mathrm{MeOH}-\mathrm{H}_{2} \mathrm{O}$ & $\mathrm{MeOH}-\mathrm{CH}_{3} \mathrm{CN}-\mathrm{H}_{2} \mathrm{O}(\mathrm{v} / \mathrm{v} / \mathrm{v})$ & \multicolumn{2}{l|}{} \\
\hline & $70: 30(\mathrm{v} / \mathrm{v})$ & $10: 50: 40$ & $20: 40: 40$ & $30: 30: 40$ \\
\hline Cinnamyl alcohol & 5.77 & 4.40 & 4.05 & 5.57 \\
\hline Eugenol & 8.80 & 6.51 & 7.38 & 8.37 \\
\hline Isoeugenol & 9.49 & 6.85 & 7.89 & $-40: 20$ \\
\hline Eugenol methyl ether & 13.92 & 9.73 & 11.31 & 3.98 \\
\hline a-Asarone & 15.43 & 10.56 & 12.48 & 12.94 \\
\hline Myristicin & 18.87 & 12.56 & 14.96 & 14.38 \\
\hline Sarfole & 19.73 & 13.95 & 16.72 & 17.20 \\
\hline 4-Allylanisole & 22.45 & 15.47 & 18.37 & 5.13 \\
\hline Trans-anethole & 27.37 & 16.64 & 19.92 & 5.15 \\
\hline
\end{tabular}

Not determined

Table 1: Effect of different mobile phase on the retention time (min) of fragrances on a $250 \times 4.6 \mathrm{~mm}$ Phenomnex $\mathrm{C}_{18}$ column.

deviation values were between $0.05 \%$ and $0.79 \%$. The correlation coefficient ranged between 0.9990 and 0.9999 .

\section{Application to essential oils}

The proposed LC-FD procedure was used to analyze the allergens of fragrances in essential oils. The primary purpose was to find allergens in these samples. With the aid of authentic reference samples, the amounts of these nine compounds in the essential oils were determined. The identity of the registered peaks was confirmed first by comparing the observed retention times of the peaks with

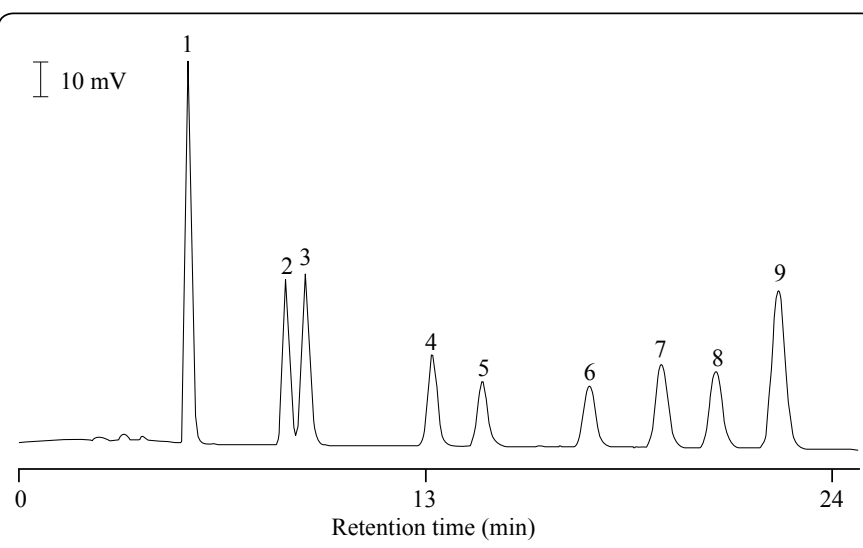

Figure 1: Separation of fragrances standards. A Phenomnex $C_{18}$ analytical column (particle size $5 \mu \mathrm{m}, 4.6 \times 250 \mathrm{~mm}$ i.d.) eluted with acetonitrile-methanolwater (30:30:40, v/v/v, pH 6.02) containing $1.0 \mathrm{mM}$ of phosphoric acid, flow rate $1.0 \mathrm{~mL} \mathrm{~min}^{-1}$, Peak identification: (1) cinnamyl alcohol $\left(250 \mathrm{ng} \mathrm{mL}^{-1}\right)$; (2) eugenol (250 $\left.\mathrm{ng} \mathrm{mL}^{-1}\right)$; (3) isoeugenol (250 $\left.\mathrm{ng} \mathrm{mL}^{-1}\right)$; (4) eugenol methy ether $\left(250 \mathrm{ng} \mathrm{mL}^{-1}\right) ;(5) \mu$-asarone $\left(2.5 \mu \mathrm{g} \mathrm{mL}^{-1}\right) ;(6)$ myristicin $\left(2.5 \mu \mathrm{g} \mathrm{mL}^{-1}\right)$; (7) safrole (250 $\left.\mathrm{ng} \mathrm{mL}^{-1}\right)$; (8) 4-allylanisole $\left(250 \mathrm{ng} \mathrm{mL}^{-1}\right)$; (9) anethole (250 ng $\left.\mathrm{mL}^{-1}\right)$.

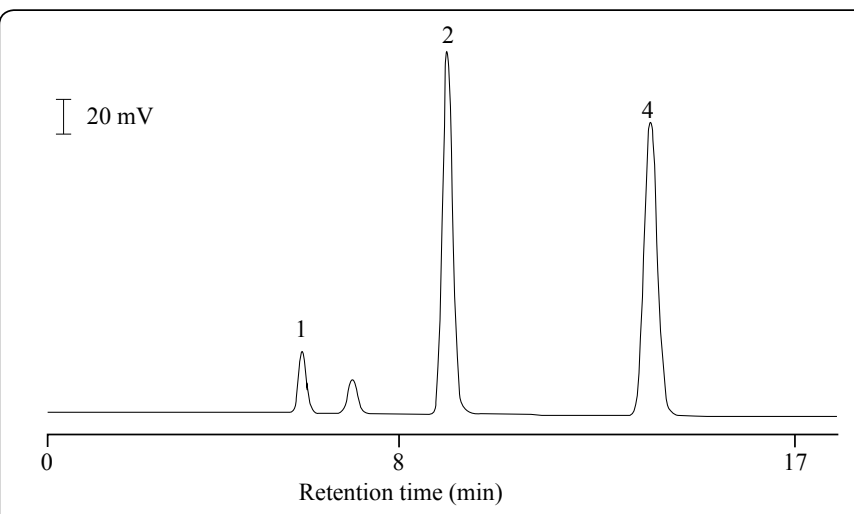

Figure 2: LC-FD chromatograms were obtained from commercial cinnamon essential oil. Peak: (1) cinnamyl alcohol; (2) eugenol; (4) eugenol methyl ether. Analysis conditions are identical to those listed in Figure 1.

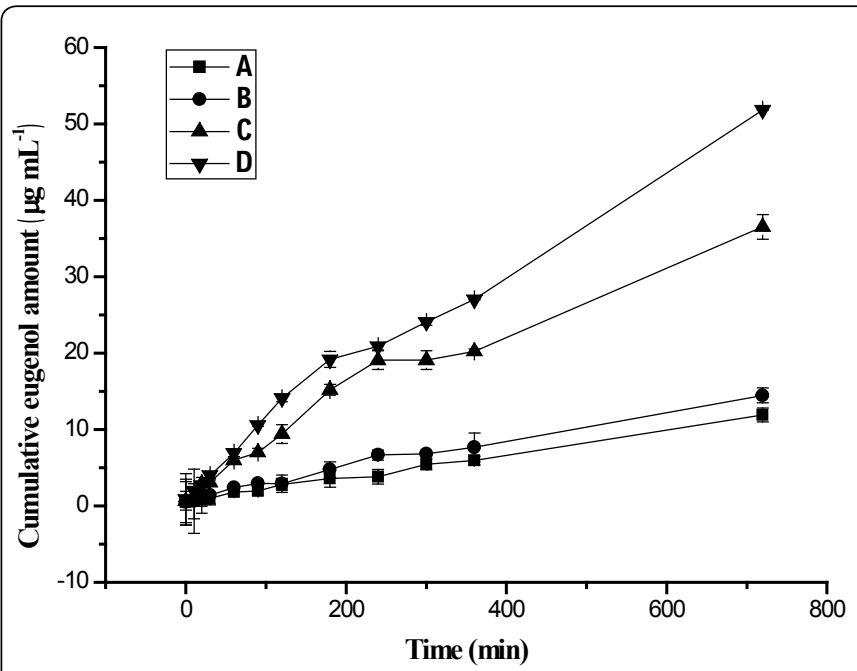

Figure 3: Effect of clove essential oil and Tween 80 on the skin permeation of eugenol in four preparations A-D; (A) without Tween 80 surfactant; (B,C and $D)$ with various amount of Tween 80 surfactants. Each point represents average \pm standard deviation $(\mathrm{N}=3$, number of determination).

those of the individual standard solutions. Figure 2 shows the HPLC of allergens from commercial cinnamon essential oil samples chromatographed using acetonitrile-methanol-water (30:30:40, $v / v / v, \mathrm{pH}$ 6.02). Analytical results essential oil of 11 from commercial products are given in Table 2 . Clove bud, basil, cinnamon, and aniseed may be used to permit the permeation of essential oil creams into the skin since the amounts of eugenol, eugenol methyl ether, and anethole were higher for these than for the other essential oils.

\section{Application to cultured epidermal autograft skin}

Clove essential oil increased the permeation of eugenol compared with those without the Tween 80 . From B, C, and D preparations, the amount of eugenol that penetrated the skin increased as the dose of clove essential oil increased (Figure 3). Tween 80 increased the percutaneous absorption of eugenol. The permeability of a drug is influenced by its physicochemical properties and by the vehicle. Based on the in vitro results, the release concentrations of fragrances for different essential oils-clove bud, cinnamon, basil, and aniseed-increased with time (Figure 4 and Figure 5).The concentration of eugenol in clove bud was higher than in the other essential oils because clove contains between 39\% and 92\% eugenol, which is released more quickly and voluminously. Nevertheless, the release rates of cinnamon and basil increased slowly and were not significantly different between 420 and $720 \mathrm{~min}$. From Table 2, three fragrances, i.e. cinnamyl alcohol $(0.28 \%)$, eugenol (3.77\%) and eugenol methyl ether (14.29\%), exists in cinnamon essential oil. According to Figure 5, the release amounts increase with time indicating that 
Citation: Wang LH, Liu HJ (2010) Determination of Fragrance Allergens in Essential Oils and Evaluation of their in vitro Permeation from Essential Oil Formulations through Cultured Skin. J Bioequiv Availab 2: 072-076. doi:10.4172/jbb.1000034

\begin{tabular}{|c|c|c|c|c|c|c|c|c|c|c|c|c|}
\hline \multirow{2}{*}{$\begin{array}{l}\text { Retention } \\
\text { No. }\end{array}$} & \multirow{2}{*}{ Compounds } & \multicolumn{11}{|c|}{ Concentration(\%, w/w)n $n=3^{\mathrm{a}}$} \\
\hline & & $\mathrm{Cl}$ & $T$ & $\mathrm{~B}$ & $\mathrm{Ci}$ & $\mathrm{A}$ & $\mathrm{G}$ & $\mathrm{C}$ & $\mathrm{R}$ & $\mathrm{J}$ & $\mathrm{L}$ & $\bar{Y}$ \\
\hline 1. & Cinnamyl alcohol & $-^{c}$ & - & $\begin{array}{c}0.05 \\
(3.20 \%)^{\mathrm{b}}\end{array}$ & $\begin{array}{c}0.28 \\
(4.20 \%)\end{array}$ & - & - & - & - & - & - & $\begin{array}{c}0.01 \\
(2.12 \%)\end{array}$ \\
\hline 2. & Eugenol & $\begin{array}{c}92.73 \\
(0.78 \%)\end{array}$ & - & $\begin{array}{c}5.63 \\
(2.52 \%)\end{array}$ & $\begin{array}{c}3.77 \\
(0.94 \%)\end{array}$ & - & $\begin{array}{c}0.75 \\
(7.03 \%)\end{array}$ & $\begin{array}{c}0.34 \\
(3.58 \%)\end{array}$ & - & - & - & $\begin{array}{c}0.001 \\
(1.15 \%)\end{array}$ \\
\hline 3. & Isoeugenol & - & - & - & - & - & - & - & $\begin{array}{c}0.11 \\
(2.33 \%)\end{array}$ & $\begin{array}{c}1.33 \\
(2.16 \%)\end{array}$ & $\begin{array}{c}0.03 \\
(3.37 \%)\end{array}$ & $\begin{array}{c}0.14 \\
(3.89 \%)\end{array}$ \\
\hline 4. & $\begin{array}{l}\text { Eugenol methyl } \\
\text { ether }\end{array}$ & $\begin{array}{c}2.16 \\
(0.21 \%)\end{array}$ & - & $\begin{array}{c}0.22 \\
(5.80 \%)\end{array}$ & $\begin{array}{c}14.29 \\
(2.27 \%)\end{array}$ & - & - & - & - & $\begin{array}{c}0.40 \\
(2 . .66 \%)\end{array}$ & - & $\begin{array}{c}2.75 \\
(3.42 \%)\end{array}$ \\
\hline 5. & a-Asarone & - & $\begin{array}{c}0.05 \\
(2.46 \%)\end{array}$ & - & - & - & - & - & - & - & - & $\begin{array}{c}0.60 \\
(3.43 \%)\end{array}$ \\
\hline 6. & Myristicin & - & - & - & - & - & - & - & - & - & - & - \\
\hline 7. & Sarfole & - & - & - & - & - & - & - & - & - & - & - \\
\hline 8. & 4-Allylanisole & - & - & $\begin{array}{c}0.78 \\
(0.38 \%)\end{array}$ & - & $\begin{array}{c}0.06 \\
(1.66 \%) \\
\end{array}$ & - & - & - & - & - & - \\
\hline 9. & Trans-Anethole & - & - & - & - & $\begin{array}{c}86.62 \\
(0.55 \%)\end{array}$ & - & - & - & - & - & $\begin{array}{c}0.05 \\
(2.80 \%)\end{array}$ \\
\hline
\end{tabular}

aNumber of determination ${ }^{\mathrm{b}}$ Coefficient of variation ${ }^{\mathrm{c}}$ Not determined

Table 2: Fragrance allylbenzenes of the essentials of clove bud $(\mathrm{Cl})$, thyme white $(T)$, basil $(B)$, cinnamon $(\mathrm{Ci})$, aniseed $(A)$, geranium $(\mathrm{G})$, clary sage $(\mathrm{C})$, rosemary $(\mathrm{R})$, jasminum $(\mathrm{J})$, lavender $(\mathrm{L})$, and ylang $(\mathrm{Y})$ using RP- HPLC with fluorometric detection.

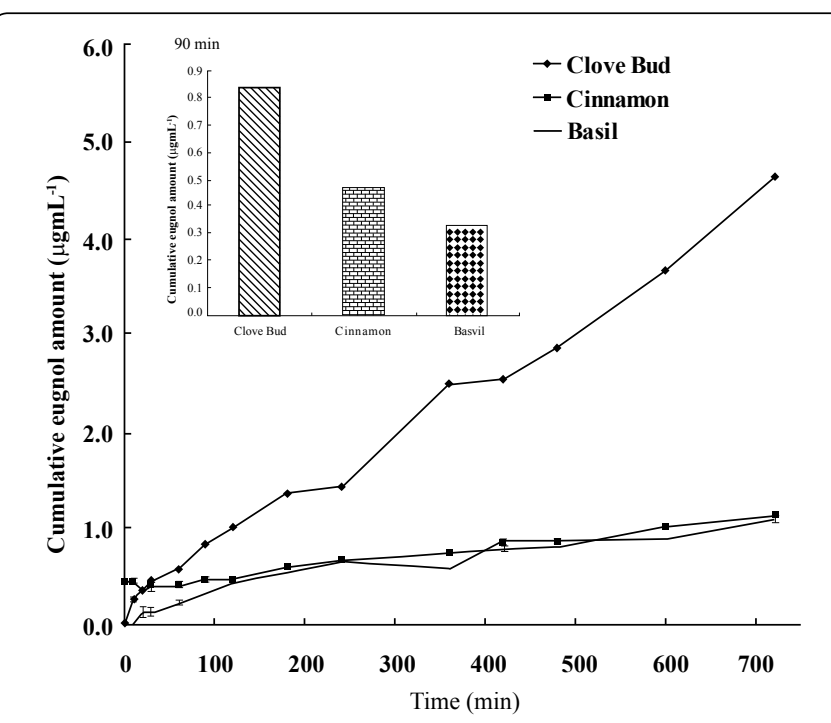

Figure 4: Cumulative amount of eugenol from clove bud, cinnamon, and basi essential oil micro-emulsions on the permeation through cultured epidermal autograft skin. Each point represents average \pm standard deviation( $\mathrm{N}=3$ number of determination ).

membrane permeations are taking place as time progresses. From the data shows that in vitro skin permeation, the eugenol methyl ether concentration in cinnamon essential oil is higher than the others.

\section{Conclusions}

This LC-FD assay for simultaneously determining the allergens in the fragrances in essential oils and in cultured epidermal autograft skin has a low detection than other analysis doses. In the essential oils from 11 commercial products, we identified 8 different allylbenzenes (eugenol, isoeugenol, eugenol methyl ether, $\alpha$-asarone, myristicin, safrole, 4-allylanisole, and trans-anethole) and 1 sensitizing fragrance. We conclude that essential oils are efficacious carriers for the transdermal delivery of fragrances because they allow the fragrances to penetrate the skin.

\section{Acknowledgments}

This work was financially supported by grant NSC 96-2113-M-041-003-MY3 from the National Science Council, Taiwan. R.O.C.

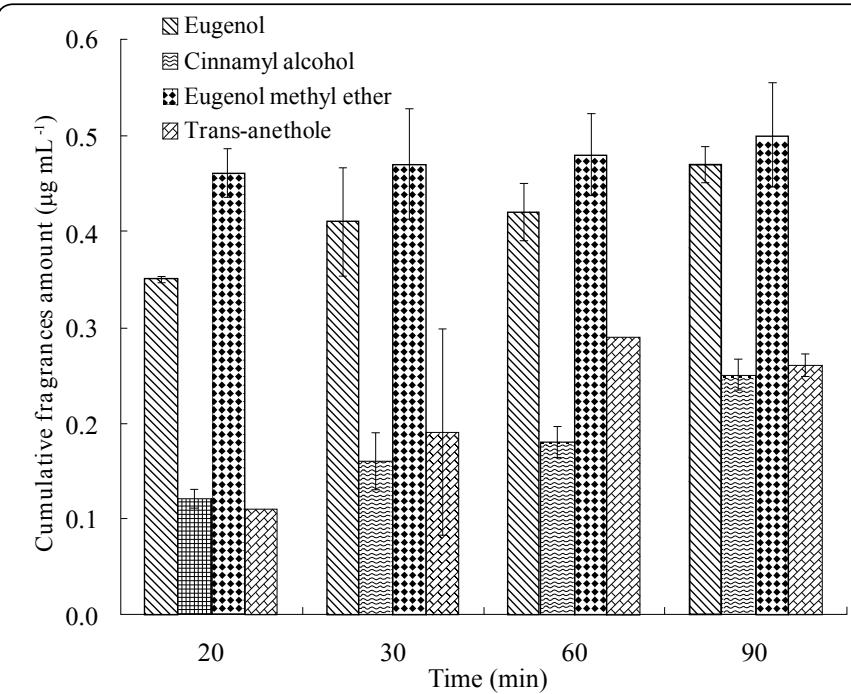

Figure 5: Cumulative amount of eugenol, cinnamyl alcohol, and eugenol methyl ether from cinnamon; and trans-anethole from aniseed essential oil micro-emulsions on the permeation through cultured epidermal autograft skin. Each point represents average \pm standard deviation $(\mathrm{N}=3$, number of determination )

\section{References}

1. An S, Lee AY, Lee CH, Kim DW, Hahm JH, et al. (2005) Fragrance contact dermatitis in Korea: a joint study. Contact Dermatitis 53: 320-323. "CrossRef " PubMed " Google Scholar

2. Besharati-Seidani A, Jabbari A, Yamini Y (2005) Headspace solvent microextraction: a very rapid method for identification of volatile components of Iranian Pimpinella anisum seed. Anal Chim Acta 530: 155-161. » CrossRef » PubMed " Google Scholar

3. Bianchi G, Nuzzi M, Leva AA, Rizzolo A (2007) Development of a headspacesolid phase micro extraction method to monitor changes in volatile profile of rose (Rosa hybrida, cv David Austin) petals during processing. J Chromatogr A 1150: 190-197. " CrossRef » PubMed " Google Scholar

4. Cadby P, Youssefi MJ, Chaintreau A (2003) Strategies to analyze suspected allergens in fragrances. Perfumer Flavorist 28: 44-53. "CrossRef " PubMed " Google Scholar

5. David F, Devos C, Joulain D, Chaintreau A, Sandra P (2006) Determination of suspected allergens in non volatile matrices using PTV injection with automated liner exchange and GC-MS. J Sep Sci 29: 1587-1594. »CrossRef » PubMed » Google Scholar

6. Elzaawely AA, Xuan TD, Tawata S (2007) Essential oils, kava pyrones and 
phenolic compounds from leaves and rhizomes of Alpinia zerumbet (Pers.) B.L. Burtt. \& R.M. Sm. and their antioxidant activity. Food Chem 103: 486-494. "CrossRef » PubMed " Google Schola

7. Gabbanini S, Lucchi E, Carli M, Berlini E, Minghetti A, et al. (2009) In vitro evaluation of the permeation through reconstructed human epidermis of essentials oils from cosmetic formulations. J Pharm Biomed Anal 50: 370-376. "CrossRef » PubMed » Google Scholar

8. Hanson KM, Gayton-Ely M, Holland LA, Zehr PS, Soderberg BCG (2005) Rapid assessment of $\beta$-asarone content of Acorus calamus by micellar electrokinetic chromatography. Electrophoresis 26: 943-946. " CrossRef » PubMed » Google Scholar

9. Hérent M-F, De Bie V, Tilqui B (2007) Determination of new retention indices for quick identification of essential oils compounds. J Pharm Biomed Anal 43: 886-892. " CrossRef " PubMed " Google Scholar

10. Huhn C, Puetz M, Holthausen I, Pyell U (2008) Separation of very hydrophobic analytes by micellar electrokinetic chromatography. I. Optimization of the composition of the sample solution for the determination of the aromatic ingredients of sassafras and other essential oils of forensic interest. Electrophoresis 29: 526-537. " CrossRef » PubMed » Google Scholar

11. Kim MR, Abd El-Aty AM, Kim IS, Shim JH (2006) Determination of volatile flavor components in danggui cultivars by solvent free injection and hydrodistillation followed by gas chromatographic-mass spectrometric analysis. J Chromatogr A 1116: 259-264. »CrossRef » PubMed » Google Scholar

12. Leijs H, Broekhans J, van Pelt L, Mussinan C (2005) Quantitative analysis of the 26 allergens for cosmetic labeling in fragrance raw materials and perfume oils. J Agri and Food Chem 53: 5487-5491. " CrossRef » PubMed » Google Scholar

13. Li T, Zhang Z, Jiao H, Lu Z, Tian Y, et al. (2007) Determination of anethole trithione in human plasma using high performance liquid chromatography coupled with tandem mass spectrometric detection. Anal Chim Acta 594: 274 278. "CrossRef » PubMed » Google Scholar

14. Li W, Deng J, Qiao J, Li Q, Zhang Y (2008) HPLC determination of 4-hydroxyanethole trithione in plasma via enzymatic hydrolysis and its application to bioequivalence study. J Pharm Biomed Anal. 47: 612-617. "CrossRef » PubMed » Google Scholar

15. Luan F, Mosandl A, Münch A, Wüst M (2005) Metabolism of geraniol in grape berry mesocarp of Vitis vinifera L. Cv. Scheurebe: demonstration of stereoselective reduction, E/Z-isomerization, oxidation and glycosylation. Phytochemistry 66: 295-303. "CrossRef » PubMed » Google Scholar

16. Lukić I, Banović M, Peršurić Đ, Radeka S, Sladonja B (2006) Determination of volatile compounds in grape distillates by solid-phase extraction and gas chromatography. J Chromatogr A 1101: 238-244. » CrossRef » PubMed » Google Scholar

17. Mitja K, Dea B, Mirko P, Križman M, Baričevič D, et al. (2006) Fast quantitative determination of volatile constituents in fennel by headspace-gas chromatography. Anal Chim Acta 557: 267-271. » CrossRef » PubMed » Google Scholar

18. Peña-Alvarez A, Capella $S$, Juárez R, Labastida C (2006) Determination of terpenes in tequila by solid phase microextraction-gas chromatography-mass spectrometry. J Chromatogr A 1134: 291-297. »CrossRef » PubMed » Google Scholar

19. Polzin GM, Stanfill SB, Brown CR, Ashley DL, Watson CH (2007) Determination of eugenol, anethole, and coumarin in the mainstream cigarette smoke of
Indonesian clove cigarettes. Food Chem Toxicol 45: 1948-1953. ” CrossRef "PubMed " Google Scholar

20. Rauber Cda S, Guterres SS, Schapoval EE (2005) LC determination of citral in Cymbopogon citratus volatile oil. J Pharm Biomed Anal 37: 597-601. » CrossRe "PubMed " Google Scholar

21. Sánchez-Palomo E, Díaz-Maroto MC, Pérez-Coello MS (2005) Rapid determination of volatile compounds in grapes by HS-SPME coupled with GCMS. Talanta 66: 1152-1157. » CrossRef » PubMed » Google Scholar

22. Schlede E, Aberer W, Fuchs T, Gerner I, Lessmann H, et al. (2008) Chemical substances and contact allergy: 244 substances ranked according to allergenic potency. In Marzulli and Maibach's Dermatotoxicology, (7th Edition), Zhai, H., Wilhelm, K-P., Maibach, H.I. (Eds). Boca Raton, FL: CRC Press, Taylor \& Francis Group, pp807-837. " CrossRef » PubMed " Google Scholar

23. Schreiner M, Peiser M, Briechle D, Stahlmann R, Zuberbier T, et al. (2008) A new dendritic cell type suitable as sentinel of contact allergens. Toxicology 249 146-152. " CrossRef » PubMed » Google Scholar

24. Schulz H, Schrader B, Quilitzsch R, Pfeffer S, Kruger H (2003) Rapid classification of basil chemotypes by various vibrational spectroscopy methods. J Agri Food Chem 51: 2475-2481. »CrossRef » PubMed » Google Scholar

25. Schulz K, Schlenz K, Malt S, Metasch R, Römhild W, et al. (2008a) Headspace solid-phase microextraction-gas chromatography-mass spectrometry for the quantitative determination of the characteristic flavouring agent eugenol in serum samples after enzymatic cleavage to validate post-offence alcohol drinking claims. J Chromatogr A 1211: 113-119. » CrossRef » PubMed » Google Scholar

26. Schulz K, Schlenz K, Metasch R, Malt S, Römhild W, et al. (2008b) Determination of anethole in serum samples by headspace solid-phase microextraction-gas chromatography-mass spectrometry for congener analysis. J Chromatogr A 1200: 235-241. »CrossRef » PubMed » Google Scholar

27. Tomar J, Jain VK, Aggarwal K, Dayal S, Gupta S (2005) Contact allergies to cosmetics: testing with 52 cosmetic ingredients and personal products. J Dermatol 32: 951-955. »CrossRef » PubMed » Google Scholar

28. Villa C, Gambaro R, Mariani E, Dorato S (2007) High-performance liquid chromatographic method for the simultaneous determination of 24 fragrance allergens to study scented products. J Pharm Biomed Anal 44: 755-762. "CrossRef " PubMed " Google Scholar

29. Weibel H, Hansen J (1989) Penetration of the fragrance compounds, cinnamaldehyde and cinnamyl alcohol, through human skin in vitro. Contact Dermatitis 20: 167-72. „CrossRef » PubMed » Google Scholar

30. Weyers W, Brodbeck R (1989) Skin permeation of essential oils Pharmacokinetic. Pharm Unserer Zeit 18: 82-6. „ CrossRef » PubMed » Google Scholar

31. Yu Y, Huang T, Yang B, Liu X, Duan G (2007) Development of gas chromatography-mass spectrometry with microwave distillation and simultaneous solid-phase microextraction for rapid determination of volatile constituents in ginger. J Pharm Biomed Anal 43: 24-31. » CrossRef » PubMed » Google Scholar

32. Zhang LC, Hu JH, Li L, Gao LH, Zhu QG, et al (2006) In vivo and in vitro evaluation of essential oils from Ligusticum chuanxiong Hort on the transdermal delivery of flurbiprofen in rabbits. Biol Pharm Bull 29: 1217-1222. "CrossRe "PubMed " Google Schola 